\title{
Unexpected presentation of Helicobacter pylori in a male child
}

\author{
Bhargavi Kola
}

Department of Pediatrics, TTUHSC, Odessa, Texas, USA

\section{Correspondence to \\ Dr Bhargavi Kola, bhargavi.kola@ttuhsc.edu}

Accepted 22 October 2018

\section{DESCRIPTION}

A 6-year-old previously healthy boy presented to paediatric clinic with increasing severity and frequency of his gag reflex over the period of 2 months. According to the parents, the child was previously healthy, immunised and no perinatal complications. His initial symptoms were nausea that was worse in lying position, occurred mostly during the night, no abdominal pain, discomfort or other associated symptoms. These symptoms gradually worsened to gagging that is constant and currently interfere with his day-to-day activity. No identifiable stressors at home or school that triggered the symptoms. No dental problems, prosthesis and regularly visits his dentist. His physical findings were normal with stable vitals and soft, non-tender abdomen with normal bowel sounds. His oral examination was unremarkable and the patient was discharged on histamine blockers for 2 weeks despite which he had no improvement. His persistent symptoms alerted the clinician for possible dental and gastrointestinal (GI) evaluation. He was cleared by the dentist but the GI specialist performed an upper GI endoscopy that revealed mildly increased intraepithelial lymphocytes (figure 1A) in the duodenum and Helicobacter pylori-like organisms immunohistochemically (figure 1B) in the duodenum and no intestinal dysplasia (figure 1C). The patient was then placed in $H$. pylori regimen with proton-pump inhibitor and two antibiotics for 14 days. A follow-up visit with GI in 8 weeks showed complete resolution of symptoms and negative non-invasive test (urea breath test) showed $H$. pylori eradication. The patient has remained asymptomatic since.

Gag reflex is a normal protective response to avoid any foreign particle to enter into the trachea, pharynx or larynx. Gagging can be elicited by tactile stimulation in the so-called 'trigger areas' of the oral cavity namely uvula, palate, palatoglossal and palate-pharyngeal folds and base of tongue. ${ }^{1}$ Exaggerated gag reflex is commonly encountered in dental procedures but other causes include:

Systematic: Chronic GI disorders, carcinoma.

Local: Nasal polyp, postnasal drip, sinusitis, nasal obstruction, hiatus hernia.

Others: visual, auditory or olfactory stimulation can also result in gagging. ${ }^{1}$

H. pylori has been the main pathogen in acute/ chronic gastritis, gastric malignancy and peptic ulcer disease ${ }^{2}$ with increasing incidence with age. Abdominal pain, nausea, cramping and dyspepsia are some of the common GI symptoms. It can get quite challenging when patients present with atypical symptoms. Some known extra intestinal associations: iron deficiency anaemia, idiopathic thrombocytopenic purpura and allergic diseases. ${ }^{3}$ Most reliable diagnosis is gastric biopsy in the paediatrics due to sampling errors with urease test (low numbers of $\mathrm{H}$. pylori in this age group). ${ }^{2}$ According to European Society and North American Society of Pediatric Gastroenterology, Hepatology and Nutrition, invasive investigations must be reserved for persistent symptoms such as vomiting, abdominal pain and GI bleed or unexplained iron deficiency anaemia, idiopathic thrombocytopenic purpura ${ }^{3}$ but not for functional abdominal pain. Treatment recommendations:

1. Clarithromycin containing regimens should be limited to paediatric age group with known susceptibility

2. In case with unknown susceptibility, high-dose triple therapy with amoxicillin, metronidazole and proton pump inhibitor should be used for a period of 14 days with strict compliance.

3. Patients should be tested with non-invasive such as stool antigen but reliable tests after 4-8 weeks of therapy.
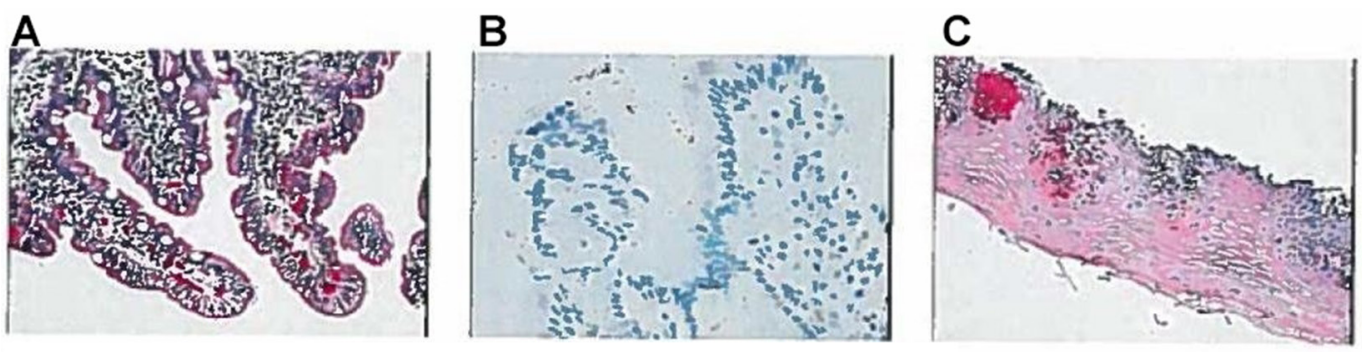

Figure 1 (A) Mildly increased intraepithelial lymphocytes in the duodenum by CD3 immunohistochemical biopsy. (B) Immune histochemical stain: Helicobacter pylori-like organisms with some degenerating organisms possibly due to concomitant antibiotic usage. (C) Negative intestinal metaplasia or dysplasia. 


\section{Learning points}

Exaggerated gag reflex in paediatric age group should signal possible aetiology other than dental procedures.

- Primary clinician should have a high index of suspicion for uncommon clinical presentations (like the one in our case) and thorough investigations should be considered to confirm the diagnosis. Gastric pathology although rare yet possible should be entertained as a differential.

Contributors BK is the sole author for the manuscript and responsible for conception, design, acquisition of the data and drafting, editing and final approval of the manuscript. As the primary author, BK is accountable for all the aspects of work.
Funding The authors have not declared a specific grant for this research from any funding agency in the public, commercial or not-for-profit sectors.

Competing interests None declared.

Patient consent Not required.

Provenance and peer review Not commissioned; externally peer reviewed.

\section{REFERENCES}

1 Bassi GS, Humphris GM, Longman LP. The etiology and management of gagging: a review of the literature. J Prosthet Dent 2004:91:459-67.

$2 \mathrm{Seo} \mathrm{JH}$, Park JS, Rhee KH, et al. Limitations of urease test in diagnosis of pediatric Helicobacter pylori infection. World J Clin Pediatr 2015; 4:143-7.

3 Jones NL, Koletzko S, Goodman K, et al. Joint ESPGHAN/NASPGHAN guidelines for the management of helicobacter pylori in children and adolescents (Update 2016). J Pediatr Gastroenterol Nutr 2017;64:991-1003.

Copyright 2018 BMJ Publishing Group. All rights reserved. For permission to reuse any of this content visit

http://group.bmj.com/group/rights-licensing/permissions.

BMJ Case Report Fellows may re-use this article for personal use and teaching without any further permission.

Become a Fellow of BMJ Case Reports today and you can:

- Submit as many cases as you like

- Enjoy fast sympathetic peer review and rapid publication of accepted articles

- Access all the published articles

Re-use any of the published material for personal use and teaching without further permission

For information on Institutional Fellowships contact consortiasales@bmjgroup.com

Visit casereports.bmj.com for more articles like this and to become a Fellow 